\title{
Pengembangan Instrumen Test Diagnostik Multiple Choice Four Tier Pada Materi Ikatan Kimia
}

\author{
Arif Yasthophi ${ }^{1)}$, Pangoloan Soleman Ritongga ${ }^{2)}$ \\ 1) Dosen Program Studi Pendidikan Kimia Fakultas Tarbiyah dan Keguruan, \\ Universitas Islam Negeri Sultan Syarif Kasim Riau, Pekanbaru \\ Email:arif.yasthophi@uin-suska.ac.id \\ ${ }^{2)}$ Dosen Program Studi Pendidikan Kimia Fakultas Tarbiyah dan Keguruan, \\ Universitas Islam Negeri Sultan Syarif Kasim Riau, Pekanbaru \\ Email:psr@uin-suska.ac.id
}

\begin{abstract}
This study was conducted to develop diagnostic tests for analysis of student misconceptions on chemical bonding materials. The developed diagnostic test is a four-level diagnostic test. This research is design and development research $(\mathrm{R} \& \mathrm{D})$. The diagnostic test consists of 25 questions consisting of 20 indicators. The istrument was validated by expert in chemical bonding material. Field test results this instrument obtained there are misconception among the subject with the highest misconception $48 \%$.
\end{abstract}

Keyword:

\section{Pendahuluan}

Ilmu kimia merupakan ilmu pengetahuan yang mengkaji materi dan perubahannya serta energi yang menyertai perubahannya. Salah satu konsep dasar ilmu kimia adalah pokok ikatan kimia. Berdasarkan Peraturan Menteri Pendidikan Nasional Nomor 22 tahun 2006, pengetahuan dasar kimia ini diajarkan pada peserta didik SMA/MA kelas X. Ilmu kimia terdiri dari konsep yang bersifat abstrak dan kompleks sehingga untuk menguasainya diperlukan pemahaman konsep yang bertahap dan mendalam. Hasil belajar yang rendah menunjukkan rendahnya pemahaman siswa terhadap suatu konsep kimia. Johnstone dalam Chittleborough, berpendapat bahwa untuk dapat memahami konsep kimia dengan benar, siswa harus bisa mendeskripsikan dan mengkaitkan aspek makroskopik (eksperimen), mikroskopik (atom, molekul, ion), dan simbolik (simbol, rumus, perhitungan) sehingga hal ini menyebabkan mata pelajaran kimia menjadi sangat kompleks. Kenyataan di sekolah siswa hanya menghafal konsep dan kurang mampu mengaitkan konsep tersebut dengan konsep lainnya yang saling berhubungan, serta kurang mampu mengaitkan konsep tersebut dengan kehidupan sehari-hari. ${ }^{1}$

Berdasarkan hasil analisis melalui jurnal-jurnal yang ada, miskonsepsi yang dialami siswa terjadi pada beberapa konsep pada materi ikatan kimia. Miskonsepsi siswa terjadi pada kenapa suatu atom berikatan satu sama lain, ikatan ion, ikatan kovalen, senyawa-senyawa kovalen, senyawa-senyawa ion dan ikatan logam.

Faktor-faktor penyebab miskonsepsi pada siswa bersumber dari siswa, guru, dan sumber belajar. $^{2}$ Penyebab miskonsepsi yang bersumber dari guru bisa terjadi karena guru kurang menguasai bahan pelajaran atau memahami pelajaran yang tidak benar. ${ }^{3}$

Sebagai seorang calon guru, sangat penting untuk menguasai dan memahami materi pelajaran dengan benar. Hasil pengamatan yang peneliti lakukan sebagai pengampu mata kuliah kajian buku ajar kimia I yang disajikan pada semester V tahun akademik 2016-2017, ada indikasi mahasiswa calon guru mengalami miskonsepsi terhadap materi ikatan kimia yang akan diajarkan pada 
kelas X di sekolah atau madrasah. Hal ini sangat mengkhawatirkan, karena pada semester VII ditahun akademik 20172018, mahasiswa calon guru tersebut akan melaksanakan PPL (Program Pengalaman Lapangan) di sekolah atau madrasah, maka perlu dilakukan proses identifikasi miskonsepsi dengan segera dan memperbaikinya serta menyampaikan konsep yang benar.

Salah satu cara untuk mengetahui miskonsepsi pada mahasiswa calon guru adalah dengan tes diagnostik. Penggunaan tes diagnostik di awal maupun di akhir pembelajaran dapat membantu peneliti menemukan miskonsepsi mahasiswa calon guru pada materi yang dipelajari. ${ }^{4}$ Tes diagnostik yang baik dapat memberikan gambaran akurat mengenai miskonsepsi yang dialami siswa berdasarkan informasi kesalahan yang dibuatnya. Pertanyaan diagnostik yang baik tidak hanya menunjukkan bahwa siswa tidak memahami bagian materi tertentu, akan tetapi juga dapat menunjukkan bagaimana siswa berpikir dalam menjawab pertanyaan yang diberikan meskipun jawaban mereka tidak benar. $^{5}$

Berbagai intrumen tes diagnostik level konsepsi pada konsep Kimia banyak dikembangkan oleh para peneliti. ${ }^{6,7,8,9,10}$ Salah satu bentuk pengembangannya ialah instrumen tes diagnostik berformat fourtier test. ${ }^{11}$ Four-tier diagnostic test (tes diagnostik empat tingkat) merupakan pengembangan dari tes diagnostik pilihan ganda tiga tingkat. Pengembangan tersebut terdapat ada ditambahkannya tingkat keyakinan siswa dalam memilih jawaban maupun alasan. Tingkat pertama merupakan soal pilihan ganda dengan tiga pengecoh dan satu kunci jawaban yang harus dipilih siswa. Tingkat ke dua merupakan tingkat keyakinan siswa dalam memilih jawaban. Tingkat ke tiga merupakan alasan siswa menjawab pertanyaan, berupa tiga pilihan alasan yang telah disediakan dan satu alasan terbuka. Tingkat ke empat merupakan tingkat keyakinan siswa dalam memilih alasan. Tingkat keyakinan yang dikembangkan berada pada rentang angka satu sampai enam sesuai dengan penelitian yang telah dilakukan oleh Caleon \& Subramaniam. ${ }^{12}$ Keunggulan yang dimiliki tes diagnostik pilihan empat tingkat adalah melalui tes diagnostik empat tingkat guru dapat: membedakan tingkat keyakinan jawaban dan tingkat keyakinan alasan yang dipilih siswa sehingga dapat menggali lebih dalam tentang kekuatan pemahaman konsep siswa, (2) mendiagnosis miskonsepsi yang dialami siswa lebih dalam, (3) menentukan bagian-bagian materi yang memerlukan penekanan lebih, (4) merencanakan pembelajaran yang lebih baik untuk membantu mengurangi miskonsepsi siswa.

Format four-tier test ini terdiri atas tier-1 berupa pertanyaan, tier-2 berupa tingkat keyakinan terhadap jawaban (tier-1), tier-3 berupa alasan terkait jawaban (tier-1), dan tier-4 berupa tingkat keyakinan terhadap alasan (tier3). ${ }^{13}$ Instrumen berformat four-tier test ini digunakan untuk mendiagnosis level konsepsi siswa pada suatu konsep kimia. Namun, hingga saat instrumen ini masih jarang digunakan.

Penelitian mengenai pengembangan instrumen tes diagnostik sudah dilakukan oleh beberapa peneliti. Penelitian yang dilakukan oleh Aldi Zulfikar dan kawan-kawan pada tahun 2017, dimana penekanan dalam penelitian ini adalah pengembangan tes diagnostik berdasarkan Force Concept Inventory Berformat Four-Tier Test pada mata pelajaran Fisika materi Gaya. Selanjutnya penelitian yang dilakukan oleh Qisthi Fariyani, Ani Rusilowati dan Sugianto. Disini, mereka meneliti mata pelajaran Fisika materi Optik Geometri. ${ }^{12}$ Perbedaan dengan penelitian yang akan dilakukan peneliti adalah subjeknya yaitu mahasiswa calon guru pendidikan kimia semester $\mathrm{V}$ pada mata pelajaran kimia dan materinya ikatan kimia. 


\section{Metode Penelitian}

Penelitian ini dilaksanakan dari bulan April sampai dengan September 2018 bertempat di Universitas Islam Negeri Sultan Syarif Kasim Riau.

$$
\text { Penelitian ini merupakan }
$$

penelitian dengan pendekatan Research and Development (R\&D). Produk yang dihasilkan dalam penelitian ini adalah instrumen four-tier diagnostic test (tes diagnostik empat tingkat) untuk mengungkap miskonsepsi mahasiswa calon guru pada materi ikatan kimia. Prosedur penelitian ini dilakukan dengan menggunakan prosedur penelitian dan pengembangan Gall et al. (2003). Tahapan pengembangan produk terdiri atas: analisis perangkat pembelajaran, penyusunan kisikisi soal tes, penulisan butir soal. Setelah butir soal disusun, dilakukan tahapan validasi yang dilakukan oleh validator yang merupakan orang yang ahli pada materi ikatan kimia. Setelah dinyatakan valid oleh validator, maka dilakukan revisi dan tahapan selanjutnya dilakukan uji coba terbatas kepada 25 orang subjek.

Teknik pengumpulan data dalam penelitian ini menggunakan metode angket validasi instrumen dan wawancara.

Diagnosis miskonsepsi dilakukan peneliti dengan mengadopsi dan mengadaptasi teknik menganalisis kombinasi jawaban untuk mengidentifikasi miskonsepsi siswa yang digunakan oleh Aldi Zulfikar. ${ }^{12}$ Mereka menggunakan Four-tier Test dengan dua opsi tingkat keyakinan yaitu yakin dan tidak yakin yang dirangkum dalam tabel 1 .

Tabel 1. Tabel Kombinasi Jawaban FourTier Test

\begin{tabular}{|c|c|c|c|c|}
\hline Tier-1 & Tier-2 & Tier-3 & Tier-4 & $\begin{array}{c}\text { Level } \\
\text { Konsepsi }\end{array}$ \\
\hline 1 & $Y$ & 1 & $Y$ & $\mathrm{U}$ \\
\hline 1 & $Y$ & 1 & TY & \\
\hline 1 & $\mathrm{TY}$ & 1 & $\mathrm{Y}$ & \\
\hline 1 & TY & 1 & TY & \\
\hline
\end{tabular}

\begin{tabular}{|c|c|c|c|c|}
\hline 1 & $\mathrm{Y}$ & 0 & $\mathrm{Y}$ & \multirow{8}{*}{ PU } \\
\hline 1 & $\mathrm{Y}$ & 0 & TY & \\
\hline 1 & TY & 0 & $\mathrm{Y}$ & \\
\hline 1 & TY & 0 & TY & \\
\hline 0 & $Y$ & 1 & $Y$ & \\
\hline 0 & $\mathrm{Y}$ & 1 & TY & \\
\hline 0 & TY & 1 & $\mathrm{Y}$ & \\
\hline 0 & TY & 1 & TY & \\
\hline 0 & $Y$ & 0 & $Y$ & $\mathrm{M}$ \\
\hline 0 & $Y$ & 0 & TY & \multirow{3}{*}{$\mathrm{NU}$} \\
\hline 0 & TY & 0 & $Y$ & \\
\hline 0 & TY & 0 & TY & \\
\hline \multicolumn{4}{|c|}{$\begin{array}{c}\text { Terdapat tier yang tidak } \\
\text { dijawab atau menjawab lebih } \\
\text { dari satu pilihan yang }\end{array}$} & UC \\
\hline
\end{tabular}

Keterangan :

$\mathrm{U}=$ Understand (Mahasiswa memiliki konsep yang baik)

$\mathrm{PU}=$ Partial (Mahasiswa memiliki Understanding konsep yang tidak Utuh)

$\mathrm{M}=$ Misconception (Mahasiswa memiliki miskonsepsi)

$\mathrm{NU}=$ Not $\quad$ (Mahasiswa tidak paham Understanding Konsep)

$\mathrm{UC}=$ Uncode (Tidak dapat dilakukan Koding)

$1=\quad$ (Jawaban Benar)

$0=\quad$ (Jawaban Salah)

$\mathrm{Y}=\quad$ Yakin

$\mathrm{TY}=\quad$ Tidak Yakin

Penelitian pengembangan instrumen tes diagnostik miskonsepsi four tier pada pokok bahasan ikatan kimia dilakukan melalui beberapa tahap. Tahap pertama dalam penelitian ini adalah identfikasi masalah dan pengumpulan informasi, selanjutnya desain produk dan validasi. Setelah validasi dilakukan perbaikan dan tahap akhir dilakukan uji coba

\section{Hasil dan Pembahasan}

\section{Identifikasi Masalah Dan Pengumpulan} Informasi

Tahap awal dalam penelitian pengembangan instrumen tes diagnostik four tier miskonsepsi pada pokok bahasan ikatan kimia dilakukan indentifikasi 
masalah. Iedentifikasi masalah yang dilakukan berdasarkan kajian literatur dan tinjauan langsung dilapangan. Tijauan pustaka dilakukan untuk mengidentifikasi kemungkinan terdapatnya miskonsepsi pada pokok bahasan ikatan kimia. Untuk menunjang identifikasi masalah berdasarkan tinjauan pustaka, dilakukan juga pengamatan langsung dilapangan. Pengamatan kemungkinan miskonsepsi dilakukan melalui proses perkuliahan Kajian Bahan Ajar 1 dan pada kegiatan ujian mahasiswa yang melaksanakan program pengalaman lapangan (PPL).

Berdasarkan kajian pustaka dari jurnal penelitian dan pengamatan selama proses perkuliahan Kajian Bahan Ajar 1 serta pada ujian program pengalaman lapangan memang terdapat miskonsepsi pada pokok bahasan ikatan kimia pada mahasiswa. Miskonsepsi yang terjadi hampir pada setiap sub pokok bahasan ikatan kimia. Miskonsepsi pada pokok bahasan ikatan kimia terlihat ketika mahasiswa mempresentasikan mengenai pokok bahasan ikatan kimia pada perkuliahan ikatan kimia atau pada saat menjelaskan ikatan kimia pada kegiatan ujian PPL. Miskonsepsi yang terjadi pada mahasiswa yang ditemukan yaitu:

1. Mahasiswa tidak dapat menjelaskan apa yang mempertahankan suatu senyawa dalam berikatan

2. Mahasiswa tidak bisa membedakan antara proses pembentukan ikatan ion dan ikatan kovalen

3. Mahasiswa tidak memahami pengaruh gaya elektrostatik dalam pembentukan ikatan

4. mahasiswa tidak dapat membedakan ikatan intramolekul dan antar molekul

5. mahasiswa tidak dapat menjelaskan hubungan ikatan yang terdapat pada suatu senyawa dengan sifat fisik senyawa tersebut

\section{Desain Produk dan Validasi}

Berdasarkan identifikasi masalah dan pengumpulan informasi, selnajutkanya dilakukan desain produk instrumen tes diagnostik four tier pada materi ikatan kimia. Tahan awal dalam desain produk adalah penyusunan kisi-kisi butir soal. Penyusunan kisi-kisi diawali dengan penyusunan indkator butir soal. Penyusunan indikator butir soal mengacu kepada silabus kurikulum 2013 revisi tahun 2017. Hal ini dilakukan karena sebagai mahasiswa pendidikan kimia, maka mahasiswa diharapkan menguasai materi yang akan diajarkan ketika nanti jadi guru. Dalam penyusunan butir soal, tidak semua indikator yang terdapat dalam silabus dijadikan sebagai indikator butir soal. Indikator yang dijadikan sebagai indikator butir soal dipilih bedasarkan kumungkinan terjadinya miskonsepsi berdasarkan identifikasi masalah dan pengumpulan informasi yang telah dilakukan. Setelah penentuan indikator butir soal. Tahap selanjutnya yang dilakukan adalah pembuatan butir soal. Penyusunan butir soal disusun menjadi empat tingkat (four tier). Pada tingkat pertama diberikan soal dalam bentuk objektif. Tingkat pertama ini diberikan dengan tujuan untuk mengetahui pemahaman siswa mengenai indikator yang telah disusun. Pada tingkat pertama ini diberikan empat pilihan jawaban a,b,c, dan d. Dari empat pilihan jawaban ini, terdapat satu jawaban yang benar dan tiga pilihan lain adalah pengecoh (distractor). Pengecoh ini dibuat berdasarkan kemungkinan miskonsepsi yang terdapat pada mahasiswa. Tingkat kedua dalam tes diagnostik ini adalah tingkat keyakinan jawaban. Pada tingkat ini terdapat dua pilihan yaitu yakin dan tidak yakin. Tingkat ketiga berupa pilihan alasan dari jawaban dari tingkat pertama. Pada tingkat ketiga ini, terdapat empat pilihan a, b, c dan d. Pada pilihan jawaban a, b, dan c sudah diberikan alasan yang mungkin dan pada pilihan disediakan ruang jika mahasiswa mempunyai pilihan jawaban lain yang tidak terdapat pada pilihan 
jawaban. Pada tingkat keempat berupa tingkat keyakinan terhadap alasan yang diberikan. Tingkat keempat ini terdiri dari dua pilihan, yakin atau tidak yakin.

Setelah penyusunan butir soal berdasarkan indikator butir soal, diperoleh soal untuk tes diagnostik sebanyak 25 butir soal. Distribusi butir soal berdasarkan indikator butir soal dapat dilihat pada tabel berikut:

Tabel 2. distribusi indikator butir soal pada butir soal desertai tingkatan taksonomi Bloom

\begin{tabular}{|c|c|c|c|}
\hline NO & INDIKATOR & $\begin{array}{l}\text { TAKSONOMI } \\
\text { BLOOM }\end{array}$ & $\begin{array}{l}\text { NO. } \\
\text { SOAL }\end{array}$ \\
\hline 1 & $\begin{array}{l}\text { Mahasiswa mampu menganalisis kecencerungan suatu } \\
\text { unsur untuk mencapai kestabilan }\end{array}$ & $\mathrm{C} 4$ & 1,2 \\
\hline 2 & $\begin{array}{l}\text { Mahasiswa mampu menentukan penyusun senyawa } \\
\text { ionik }\end{array}$ & C3 & 3 \\
\hline 3 & $\begin{array}{l}\text { Mahasiswa mampu mendeteksi penyebab terbentuknya } \\
\text { ikatan dalam senyawa ion }\end{array}$ & $\mathrm{C} 4$ & 4 \\
\hline 4 & $\begin{array}{l}\text { Mahasiswa mampu menafsirkan peristiwa terbentuknya } \\
\text { ikatan }\end{array}$ & $\mathrm{C} 5$ & 5 \\
\hline 5 & $\begin{array}{l}\text { Mahasiswa mampu menentukan jenis ikatan dalam suatu } \\
\text { senyawa }\end{array}$ & $\mathrm{C} 3$ & 6 \\
\hline 6 & $\begin{array}{l}\text { Mahasiswa mampu menyimpulkan penyebab suatu atom } \\
\text { atau ion dapat begabung sehingga membentuk suatu } \\
\text { padatan }\end{array}$ & $\mathrm{C} 5$ & 7 \\
\hline 7 & $\begin{array}{l}\text { Mahasiswa dapat menentukan daya hantar listrik } \\
\text { senyawa dalam fasa padat dan lelehan }\end{array}$ & $\mathrm{C} 3$ & 8,9 \\
\hline 8 & $\begin{array}{l}\text { Mahasiswa mampu menganalisis terbentuknya ikatan } \\
\text { dari dua atom berdasarkan nomor atom }\end{array}$ & $\mathrm{C} 4$ & 10 \\
\hline 9 & $\begin{array}{l}\text { Mahasiswa mampu menelaah jumlah ikatan yang } \\
\text { terbentuk dari suatu senyawa berdasarkan nomor atom }\end{array}$ & $\mathrm{C} 4$ & 11 \\
\hline 10 & $\begin{array}{l}\text { Mahasiswa mampu membnadingkan titik didih dari dua } \\
\text { senyawa yang segolongan bedarsarkan gaya antar } \\
\text { molekul }\end{array}$ & $\mathrm{C} 4$ & 12 \\
\hline 11 & $\begin{array}{l}\text { Mahasiswa mampu mendeteksi senyawa yang mungkin } \\
\text { dilepaskan dari pemanasan larutan } \mathrm{NaCl}\end{array}$ & $\mathrm{C} 4$ & 13 \\
\hline 12 & $\begin{array}{l}\text { Mahasiswa mampu menganalisis peristiwa pelarutan } \\
\text { senyawa kovalen }\end{array}$ & $\mathrm{C} 4$ & 14 \\
\hline 13 & $\begin{array}{l}\text { Mamhasiswa mampu menganalisis terbentuknya ikatan } \\
\text { dari dua atom berdasarkan nomor atomnya }\end{array}$ & $\mathrm{C} 4$ & 15 \\
\hline 14 & $\begin{array}{l}\text { Mahasiswa mampu mendeteksi senyawa yang mungkin } \\
\text { dilepaskan dari pemanasan larutan } \mathrm{NaCl}\end{array}$ & $\mathrm{C} 4$ & 16 \\
\hline 15 & $\begin{array}{l}\text { Mahasiswa mampu mengalisis ikatan perubahan ikatan } \\
\text { yang terjadi pada perubahan wujud suatu zat }\end{array}$ & $\mathrm{C} 4$ & 17 \\
\hline 16 & Mahasiswa membandingkan kepolaran suatu senyawa & $\mathrm{C} 5$ & 18 \\
\hline 17 & $\begin{array}{l}\text { Mahasiswa mampu membandingkan titik didih suatu } \\
\text { senyawa berdasarkan ikatan intra dan antar molekulnya }\end{array}$ & $\mathrm{C} 5$ & 19 \\
\hline 18 & $\begin{array}{l}\text { Mahasiswa mampu mengalisis jumlah ikatan yang } \\
\text { terdapat dalam suatu senyawa }\end{array}$ & $\mathrm{C} 4$ & $\begin{array}{l}20,23, \\
24,25\end{array}$ \\
\hline 19 & $\begin{array}{l}\text { Mahasiswa mampu membandingkan kekuatan ikatan } \\
\text { kimia }\end{array}$ & $\mathrm{C} 5$ & 21 \\
\hline
\end{tabular}




\section{Mahasiswa mampu membandingkan kekuatan ikatan antar molekul dari suatu senyawa \\ Pada tabel 2 terlihat juga tingkat kognitif butir soal berdasarkan taksonomi Bloom. Pembegaian tingakt taksonomi blom pada instrumen tes diagnostik four tier ini dimulai dari C3 hingga C5. Pemilihan tingak ini dilakukan karena untuk menggali miskonsepsi yang mungkin terjadi hanya dapat digali pada tingkatan $\mathrm{C} 3$ yaitu menerapkan, $\mathrm{C} 4$ menganalisi, C5 mengevaluasi. Peneliti tidak memasukkan tingkat $\mathrm{C} 1$ mengingat dan $\mathrm{C} 2$ memahami karena pada tingkatan ini kemungkinan \\ Setelah penyusunan butir soal instrumen tes diagnostik foru tier, dilakukan tahapan validasi. Validasi dilakukan untuk mengetahui kualitas dari butir soal yang telah dibuat. Validasi butir soal dilakukan oleh ibu Dr. Yenni Kurniawati, M.Si. validator ini menyelesaikan S1 dan S2 pada bidang ilmu kimia anorganik yang berkaitan langsung dengan materi ikatan kimia dan beliau menyelesaikan S3 pada bidang pendidikan kimia.} miskonsepsi dapat digali sangat kecil, karena berdasarkan kajian literatur berdasarkan penelitian sebelumnya, miskonsepsi tidak dapat digali secara maksimal pada tingkat $\mathrm{C} 1$ karena adanya kemungkinan mahasiswa hanya mengetahui dengan mengandalkan ingatannya saja.

\section{Perbaikan Produk Tes Diagnostik Four Tier}

Setelah divalidasi oleh validator didapatkan beberapa koreksian pada butir soal yang telah dibuat yaitu:

Tabel 3 Hasil validasi dan perbaikan butir soal tes diagnostik foau tier miskonsepsi pada materi ikatan kimia

\begin{tabular}{|c|c|c|}
\hline No soal & Validasi & Perbaikan setelah validasi \\
\hline 1 & Tidak ada perbaikan & Tidak berubah \\
\hline 2 & 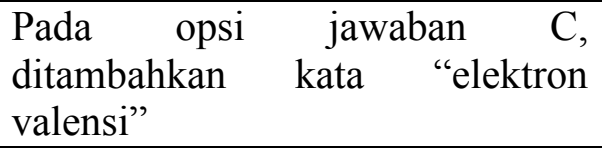 & Ditambahkan kata "elektron valensi" \\
\hline 3 & $\begin{array}{l}\text { Kata partikel pada kaliamat } \\
\text { "partikel penyusun senyawa } \mathrm{NaCl} \\
\text { adalah...." dihilangkan atau } \\
\text { diganti }\end{array}$ & $\begin{array}{l}\text { Kata partikel dihilangkan dan kalimat } \\
\text { berubah menjadi "Penyusun senyawa } \mathrm{NaCl} \\
\text { adalah..." }\end{array}$ \\
\hline 4 & $\begin{array}{l}\text { Terdapat perbedaan informasi } \\
\text { unsur yang diberikan dengan } \\
\text { pertanyaan }\end{array}$ & $\begin{array}{lrr}\text { Dilakukan perbaikan } & \text { informasi } & \text { soal } \\
\text { berdasarkan pernyataan } & & \end{array}$ \\
\hline 5 & Tidak ada perbaikan & Tidak berubah \\
\hline 6 & $\begin{array}{l}\text { Pada soal ini } \text { validator } \\
\text { menyarankan alasan yang tepat } \\
\text { diberikan pada } \\
\text { kemungkinan alasan pada pilihan } \\
\text { a, b atau c. }\end{array}$ & $\begin{array}{l}\text { Tidak mengalami perubahan. Hal ini karena } \\
\text { dengan memvariasikan opsi jawaban akan } \\
\text { membuat soal menjadi lebih baik dalam } \\
\text { menggali miskonsepsi pada mahasiswa }\end{array}$ \\
\hline 7 & Tidak ada perbaikan & Tidak berubah \\
\hline 8 & $\begin{array}{l}\text { Pada soal ini } \text { validator } \\
\text { menyarankan alasan yang tepat } \\
\text { diberikan pada pilihan } \\
\text { kemungkinan alasan pada pilihan } \\
\text { a, b atau c. }\end{array}$ & $\begin{array}{l}\text { Tidak mengalami perubahan. Hal ini karena } \\
\text { dengan memvariasikan opsi jawaban akan } \\
\text { membuat soal menjadi lebih baik dalam } \\
\text { menggali miskonsepsi pada mahasiswa }\end{array}$ \\
\hline 9 & Tidak ada perbaikan & Tidak berubah \\
\hline
\end{tabular}




\begin{tabular}{|c|c|}
\hline 10 & Tidak ada perbaikan \\
\hline 11 & $\begin{array}{l}\text { Validator } \\
\text { pemberian gambar struktur dari } \\
\text { senyawa } \mathrm{H}_{2} \mathrm{CO}_{3} \text { pada alasan. }\end{array}$ \\
\hline 12 & $\begin{array}{l}\text { Pada soal digunakan kalimat } \\
\text { " } \mathrm{H}_{2} \mathrm{O} \text { dan } \mathrm{H}_{2} \mathrm{~S} \text { adalah senyawa } \\
\text { yang memiliki bentuk yang } \\
\text { serupa" kata bentuk disarankan } \\
\text { untuk diperjelas dengan } \\
\text { menambahkan bentuk apa yang } \\
\text { dimaksudkan. }\end{array}$ \\
\hline 13 & $\begin{array}{l}\text { Alasan pada jawaban } \\
\text { ditambahkan fasa dari senyawa }\end{array}$ \\
\hline 14 & $\begin{array}{l}\text { Kata terurai pada soal disarankan } \\
\text { untuk dirubah }\end{array}$ \\
\hline 15 & Tidak ada perbaikan \\
\hline 16 & Tidak ada perbaikan \\
\hline 17 & Kata "perubahan" dihilangkan \\
\hline 18 & Tidak ada perbaikan \\
\hline 19 & $\begin{array}{l}\text { Kata "berat molekul" sebaiknya } \\
\text { diganti dengan kata "massa } \\
\text { molekul relatif" }\end{array}$ \\
\hline 20 & Soal sedikit membingungkan \\
\hline 21 & Tidak ada perbaikan \\
\hline 22 & $\begin{array}{l}\text { Pada soal ini validator } \\
\text { menyarankan alasan yang tepat } \\
\text { diberikan pada pilihan } \\
\text { kemungkinan alasan pada pilihan } \\
\text { a, b atau c. }\end{array}$ \\
\hline 23 & $\begin{array}{l}\text { Penambahan kata hubung "dan" } \\
\text { pada opsi jawaban a dan b }\end{array}$ \\
\hline 24 & Tidak ada perbaikan \\
\hline 25 & Tidak ada perbaikan \\
\hline
\end{tabular}

Koreksian secara umum dari validator antara lain pada perintah pilihan tingkat keyakinan, ditambahkan kata "tingkat keyakinan jawaban dan tingkat keyakinan alasan". Selain itu validator juga menyarankan pemberian ruang yang lebih besar pada opsi pilihan alasan d, sehingga mahasiswa memiliki ruang lebih untuk menuangkan alasannya. Saran secara umum yang diberikan validator ini sudah diikuti dan kesimpulan penilaian validator
Tidak berubah

Tidak mengalami perubahan. Hal ini karena peneliti merasa dengan memberikan gambar struktur pada senyawa akan mengurangi tingkatan kognitif dari soal karena membuat mahasiswa hanya memilih dari gambar dan tidak memerlukan analisis dalam pembuatan gambar dari senyawa tersebut

Ditambahkan kata-kata bentuk struktur molekul yang sama, maka kalimat berubah menjadi " $\mathrm{H}_{2} \mathrm{O}$ dan $\mathrm{H}_{2} \mathrm{~S}$ adalah senyawa yang memiliki bentuk struktur molekul yang sama".

Ditambahkan fasa dari senyawa pada jawaban.

Kata terurai dihilangkan

Tidak berubah

Tidak berubah

Kata "perubahan" dihilangkan

Tidak berubah

Kata "berat molekul" diganti dengan kata "massa molekul relatif"

Dilakukan perbaikan dalam penyusunan kata-kata dari soal

Tidak berubah

Tidak mengalami perubahan. Hal ini karena dengan memvariasikan opsi jawaban akan membuat soal menjadi lebih baik dalam menggali miskonsepsi pada mahasiswa

Ditambahkan kata hubung "dan"

Tidak berubah

Tidak berubah adalah bahwa konten yang terdapat pada butir soal sudah sangat baik untuk menggali miskonsepsi yang munkin terdapat pada mahasiswa.

\section{Hasil Uji Coba}

Soal yang sudah dinyatakan valid oleh validator, soal tersebut digunakan untuk uji coba terbatas kepada mahasiswa Program Studi Pendidikan Kimia Fakultas Tarbiyah dan Kehuruan UIN Suska Riau. Hasil uji coba dapat dilihat pada tabel berikut : 
Tabel 4 Hasil Uji Coba Terbatas

\begin{tabular}{|c|c|}
\hline $\begin{array}{c}\text { NO } \\
\text { SOAL }\end{array}$ & PERSENTASE \\
\hline 1 & $40 \%$ \\
\hline 2 & $0 \%$ \\
\hline 3 & $4 \%$ \\
\hline 4 & $44 \%$ \\
\hline 5 & $0 \%$ \\
\hline 6 & $48 \%$ \\
\hline 7 & $20 \%$ \\
\hline 8 & $4 \%$ \\
\hline 9 & $32 \%$ \\
\hline 10 & $24 \%$ \\
\hline 11 & $32 \%$ \\
\hline 12 & $4 \%$ \\
\hline 13 & $12 \%$ \\
\hline 14 & $4 \%$ \\
\hline 15 & $12 \%$ \\
\hline 16 & $40 \%$ \\
\hline 17 & $32 \%$ \\
\hline 18 & $8 \%$ \\
\hline 19 & $24 \%$ \\
\hline 20 & $40 \%$ \\
\hline 21 & $20 \%$ \\
\hline 22 & $24 \%$ \\
\hline 23 & $0 \%$ \\
\hline 24 & $4 \%$ \\
\hline 25 & $16 \%$ \\
\hline
\end{tabular}

Berdasarkan hasil uji coba terdapat beberapa soal yang dapat mengukur miskonsepsi pada mahasiswa, seperti pada soal nomor $1,4,6,16$, dan 20 dimana ditemukan miskonsepsi mahasiswa dengan jumlah $\geq 40 \%$. Namun, beberapa soal juga menunjukkan tidak terjadi miskonsepsi seperti pada soal nomor 2, 5 dan 23.

Ucapan Terima Kasih

Terima kasih kami ucapkan kepada Lembaga Penelitian dan Pengabdian Kepada Masyarakat (LPPM) UIN Sultan Syarif Kasim Riau yang telah membantu mendanai Penelitian ini.

\section{Daftar Pustaka}

[1] Zulfadli dan Iffah Munawwarah, Identifikasi Pemahaman Siswa Terhadap Konsep Kelarutan dan
Hasil Kali Kelarutan dengan Menggunakan Tes Diagnostik ThreeTier Multiple Choice, Jurnal Edukasi Kimia, 2016, 1 (1), e-ISSN: 25487825, p-ISSN: 2548-4303, h. 32-40.

[2] Luh Mentari, I Nyoman Suardana, dan I Wayan Subagia, Analisis Miskonsepsi Siswa Sma Pada Pembelajaran Kimia Untuk Materi Larutan Penyangga, e-Journal Kimia Visvitalis Universitas Pendidikan Ganesha, Volume 2 Nomor 1 Tahun 2014, h. 76-87

[3] Paul Suparno. Miskonsepsi dan Perubahan Konsep Pendidikan Fisika. Jakarta: PT. Grasindo. 2005, h. 30-31.

[4] Lin, S. Development and Application of a Two-Tier Diagnostic Test for High School Students' Understanding of Flowering Plant Growth and Development. International Journal of Science and Mathematics Education, 2: 2004. H. 175-199.

[5] Law, J. F. \& Treagust, D. F. Diagnosis of Student Understanding of Content Specific Science Areas Using On-Line Two-Tier Diagnostic Tests. Australia: Curtin University of Technology. 2010

[6] Arslan, A.S. Devecioglu, Y. Student Teachers' Levels of Understanding and Model of Understanding about Newton's Laws of Motion. AsiaPacific on Science Learning and Teaching. 11(1). 2010. h. 1-20.

[7] Gurel, D.K., Eryilmaz A., McDermott, L.C. A Review and Comparison of Diagnostic Instruments to Identify Students' Misconceptions in Science. Eurasia Journal of Mathematics, Science and Technology Education. 11(5). 2015. h. 989-1008.

[8] Uyulgan, M.A., Akkuzu, N., Alpat, S. Assesing the Students' Understanding Related to Molecular Geometry Using A Two-Tier Diagnostic Test. Journal of Baltic 
Science Education. 13(6). 2014. h. 839-855.

[9] Pesman, H., Eryilmaz, A. Development of Three-Tier Test to Assess Misconceptions about Simple Electric Circuits. Journal of Educational Research. 2010. h. 103: 208-222.

[10] Ismail, I.I., Samsudin, A., Suhendi, E., Kaniawati, I. (2015). Diagnostik Miskonsepsi Melalui Listrik Dinamis Four Tier Test. In Prosiding Simposium Nasional Inovasi dan Pembelajaran Sains 2015, h. 381384. Bandung, Ina.: Simposium Nasional Inovasi dan Pembelajaran Sains.

[11] Caleon, J.S., Subramaniam, R. Do Students Know What They Know and What They Don't Know? Using a Four-Tier Test to Assess the Nature of Students' Alternative Conceptions. Research in Science Education, 40. 2010. h. 313-337.

[12] Aldi Zulfikar, Achmad Samsudin, Duden Saepuzaman, Pengembangan Terbatas Tes Diagnostik Force Concept Inventory Berformat FourTier Test, Jurnal Wahana Pendidikan Fisika, ISSN: 23381027, Februari. 2017. Vol.2 No.1. h. 43-49. 